\title{
Letter to Him
}

\author{
Mary Lin LoRÍA RodríGUez
}

$\mathrm{I}$

m not the same girl that I used to be,

What now remains is what you all can see.

Unwanted since the lightless dawn,

Despised by the Earth that cries unsound.

The womb that gave life drifts,

While the hand that nurses blood lingers.

Clutched and lifted from the sick medicine

To the dreadful solitude of his embrace.

The more you hope, the harder you fall.

The tangled ropes of Destiny don't hurt at all

Because I have learned to never fear what may befall,

My body does not sore, but my soul crawls.

I created a wall that would not easily fall,

Yet I wait for the sweet release of the sacred call.

I suffocate in an embrace that holds me too tight,

And I pray in silence for the mournful light.

I first trusted him. Now his eyes bite and leer,

Hell falls out of his mouth and miasma pours out of his spear,

His darkness weighs on me at night and lures me to sleep.

I've never wanted or asked him to stain me,

Yet he stepped across my threshold. How could he?

I'll now forever fight to escape him,

In a dreadful dream of eternal aching.

The scars are unseen in the linen of my skin,

But if you trace your fingers down them, you'll feel my soul scream.

Oh, pitiful shadow shrouded in dark ease,

Your empty soul drowns in your sins.

I look at you from above in the dazzling sea,

And ask you... Want to see how death is?

* Primer lugar de poesía en inglés, "VI Concurso de Escritura Creativa en Francés e Inglés 2013”, Escuela de Lenguas Modernas, Universidad de Costa Rica. 
